\title{
Educational workshop with adolescents on leprosy: case report
}

\author{
Oficina educativa com adolescentes sobre hanseníase: relato de experiência \\ Taller educativo con adolescentes sobre la enfermedad de Hansen (Lepra): relato de experiencia
}

\section{Bruna Hinnah Borges Martins de Freitas' ORCID: 0000-0002-2121-1785}

Fabiane Blanco e Silva' ORCID: 0000-0003-0339-9451

Hellen Cristina Dias dos Santos Silva' ORCID: 0000-0003-3262-8356

Alan Maique Ribeiro Fernandes da Costa' ORCID: 0000-0002-7986-2636

Karine Ferreira da Silva' ORCID: 0000-0003-0721-9665

Sabrina Edvirges Garcia Silva' ORCID: 0000-0001-5438-4394

'Universidade Federal de Mato Grosso. Cuiabá-MT, Brazil.

How to cite this article: Freitas BHBM, Silva FB, Silva HCDS, Costa AMRF, Silva KF, Silva SEG. Educational workshop with adolescents on leprosy: case report. Rev Bras Enferm [Internet]. 2019;72(5):1421-5. doi: http://dx.doi.org/10.1590/0034-7167-2017-0663

Corresponding Author:

Bruna Hinnah Borges Martins de Freitas E-mail: bruhinnah@gmail.com

Submission: 09-22-2017

Approval: 06-08-2018

\section{ABSTRACT}

Objective: To report the experience of professors and students in the development and implementation of an educational workshop on leprosy with adolescents. Method: This is a case report from actions contained in a university extension project. Results: The workshop program was elaborated with duration of two hours, including five dynamic techniques adapted to the topic: adjective, face, traffic light, true or false and mosaic. It was verified that the construction of knowledge in light of the verbalization of the adolescents and the interest in working in the society they live through sharing this knowledge, especially those who were more involved in the process. Conclusion: It was concluded that the applied workshops enabled building knowledge and demystifying myths and stigmas socially constructed to adolescents, as well as allowed Nursing students to experience educational interventions on leprosy with adolescents. Descriptors: Adolescent; Health Education; Health Promotion; Leprosy; Nursing Care.

\section{RESUMO}

Objetivo: Relatar a experiência de docentes e discentes na elaboração e aplicação de oficina educativa sobre hanseníase com adolescentes. Método: Trata-se de um relato de experiência a partir de ações contidas em um projeto de extensão universitária. Resultados: $O$ roteiro da oficina foi elaborado com duração de duas horas, englobando cinco técnicas de dinâmicas adaptadas à temática: adjetivo, face, semáforo, verdadeiro ou falso e mosaico. Verificou-se a construção de conhecimento diante da verbalização dos adolescentes e do interesse em atuar na sociedade em que vivem por meio do compartilhamento desse conhecimento, principalmente dos que se mostraram mais envolvidos durante o processo. Conclusão: Conclui-se que as oficinas aplicadas possibilitaram a construção do conhecimento e a desmistificação de mitos e estigmas socialmente construídos aos adolescentes, assim como permitiram aos discentes de enfermagem a vivência em intervenções educativas sobre hanseníase com adolescentes.

Descritores: Adolescentes; Educação em Saúde; Promoção da Saúde; Hanseníase; Cuidados de Enfermagem.

\section{RESUMEN}

Objetivo: Relatar la experiencia de docentes y discentes en la elaboración y en la aplicación de taller educativo sobre la enfermedad de Hansen con adolescentes. Método: Se trata de un relato de experiencia desde acciones contenidas en un proyecto de extensión universitaria. Resultados: El programa del taller fue elaborado con duración de dos horas, englobando cinco técnicas de dinámicas adaptadas a la temática: adjetivo, caras, semáforo, verdadero o falso y mosaico. Se certificó la construcción del conocimiento delante de la verbalización de los adolescentes y del interés en actuar en la sociedad en que viven por medio del compartir de ese conocimiento, principalmente de los que se mostraron más involucrados durante el proceso. Conclusión: Se concluye que los talleres aplicados posibilitaron la construcción del conocimiento y la desmitificación de mitos y estigmas socialmente construidos a los adolescentes, así como permitieron a los discentes de enfermería la vivencia en intervenciones educativas sobre enfermedad de Hansen con adolescentes.

Descriptores: Adolescentes; Educación en Salud; Promoción de la Salud; Enfermedad de Hansen; Cuidados de Enfermería. 


\section{INTRODUCTION}

Leprosy is a chronic infectious disease, known as ancient and stigmatizing illness because of the way it induces deformities and physical disabilities. Although it happens more in adults, people under 15 years are considered more susceptible to acquire an infection, especially when contacts of new cases are not treated ${ }^{(1)}$. The prevalence of the disease in this group is greater in endemic regions and suggests the precocity of the exposition, the continuity in the transmission of the bacillus and the deficiency in the surveillance and control of the disease ${ }^{(2)}$.

In 2015, 210,758 new cases of leprosy were registered in the world, with Brazil in the second position in the world ranking $(26,395$ records), and $7.35 \%$ of cases were in the population under 15 years $^{(3)}$.

In Brazil, the disease is distributed heterogeneously, showing hyperendemicity in some states, such as Mato Grosso, which recorded in that same year 93 new cases/100,000 inhabitants, and 21.3 of these in children under 15 years-old ${ }^{(4)}$. Additionally, a research performed in that state found a growing tendency of multibacillary cases and with physical disability of degree II at the moment of diagnosis over the course of thirteen years (2001-2013) in children under 15 years old, suggesting the late detection of the cases and the progress of disease complications ${ }^{(5)}$.

The disease can affect the daily life of these individuals, mainly due to signs and symptoms, which lead to frequent hospitalizations and health care for treatment and follow-ups. These events can compromise the growing and development process due to modifications in the life of affected individuals and their families, in addition to stigma and prejudice, generating losses in social relations, demanding re-adaptations in face of the new situation and strategies for coping ${ }^{(6)}$.

According to the Ministry of Health, one of the actions to reduce the burden of leprosy in Brazil is health education, which aims, above all, to encourage the spontaneous demand of individuals with suspicion to health services for screening, eliminating false concepts concerning the disease, informing about the disease signs, symptoms and timely treatment, and adopting measures to prevent disabilities ${ }^{(6)}$.

In this sense, the school environment is recognized as a privileged institutional area for developing such actions with adolescents. However, this should happen in a participatory, creative and interactive way, allowing the emancipation of the target subjects of the action, through a multifaceted and specific approach. Educational practices for this audience have better results when developed through workshops using educational games, in a relaxed way, with open communication and expression of ideas ${ }^{(7-8)}$.

An integrative review study on educational practices about leprosy with adolescents detected nine studies that developed these interventions, and changes in knowledge were observed when these were based in constructivist methods, with proper techniques to conceptions of knowledge, education and of the subjects who participated in the pedagogical intervention. Most studies mentioned the nurse as the main professional involved in these actions ${ }^{(9)}$.

\section{OBJECTIVE}

To report the experience of professors and students in the development and implementation of an educational workshop with adolescents in a hyperendemic capital in Brazil.

\section{METHOD}

This is a case report research, developed from one of the actions of the extension project"PROHANSEN: Projeto de combate à hanseníase em menores de quinze anos em Cuiabá (MT)" (Project to fight leprosy in children under 15 years in Cuiabá, MT), applied to 5th and 9th year students, aged from 10 to 14 years, enrolled in state schools in the city of Cuiabá. The objective of the educational workshops is the promotion, reflection and awareness about leprosy to the target audience.

There are 57 state schools in Cuiabá. In 2016, there were 21,886 eligible enrolled individuals, according to the State Department of Education in Mato Grosso, which authorized this project, however, the management of each school would have autonomy to accept or refuse the proposal. Thus, the workshop was performed gradually with authorization and appointment by the management of each school.

The activity was developed in small groups of participants (five to six on average). To compose these groups, the educational action was disseminated in the classrooms of each school, clarifying the objectives of the research. The Informed Consent Form was given to the interested adolescents, highlighting the importance of talking to their parents or guardians, asking them about permission to participate in the study. After parents/guardians authorization, there were guidelines regarding questions and referrals of ethical issues, then the Consent Form was signed.

In the first year of the project, from June 2016 to June 2017, the workshop was developed in 31 schools. All eligible individuals of each school had the opportunity to participate in this action, but a total of 1,263 participants was reached.

This study is part of a matrix research titled "Health education and active search of leprosy in children under 15 years in Cuiabá, MT" (Educação em saúde e busca ativa de hanseníase em menores de quinze anos em (uiabá, MT), approved by the Research Ethics Committee of the University Hospital Júlio Müller (HUJM - Hospital Universitário Júlio Müller) on 8 June 2016.

\section{BUILDING THE WORKSHOP PROGRAM}

The workshop program was developed and adapted by professors, including five dynamic techniques already known and disseminated electronically, as described in Chart 1. This choice is based on the conception that this resource has been considered potentially capable to contribute both for the development of education and for constructing knowledge in health, in addition to being a fun, stimulating and interactive activity ${ }^{(10)}$.

After making the program, a meeting was arranged with nursing undergraduate students to demonstrate the application of the workshop, so that - since it had already been used with these students - they reproduced it subsequently with adolescents during the educational intervention. 
Chart 1 - Dynamic techniques, objective, worked knowledge and application time of the educational workshop with adolescents on leprosy, Cuiabá, Mato Grosso, Brazil, 2017

\begin{tabular}{|c|l|l|c|}
\hline Technique & \multicolumn{1}{|c|}{ Objective } & \multicolumn{1}{|c|}{$\begin{array}{c}\text { Worked knowledge } \\
\text { Application } \\
\text { time }\end{array}$} \\
\hline Adjective & $\begin{array}{l}\text { To provide a moment of relaxation and interaction among the participants with } \\
\text { undergraduate students and to introduce themselves. }\end{array}$ & $\begin{array}{l}\text { Memorizing names and } \\
\text { group interaction. }\end{array}$ & \multicolumn{1}{c|}{10 minutes } \\
\hline Face & $\begin{array}{l}\text { To know the perception of school children under fifteen years old regarding leprosy } \\
\text { and the concept attributed to it. }\end{array}$ & Concept, fear and stigma. & 30 minutes \\
\hline Traffic light & $\begin{array}{l}\text { To know the perception about classification, signs, symptoms and leprosy } \\
\text { transmission. }\end{array}$ & $\begin{array}{l}\text { Classification, signs, } \\
\text { symptoms and transmission. }\end{array}$ & 30 minutes \\
\hline True or false & To know the perception on leprosy diagnosis and treatment. & Diagnosis and treatment. & 30 minutes \\
\hline Mosaic & To know the meaning attributed by the students regarding educational intervention. & - & 20 minutes \\
\hline
\end{tabular}

At first, the adjective dynamic technique was performed as an icebreaker, which was developed in a way that each one mentioned their own name with an adjective starting with the same initial of their name - for example: Loving Luke. The following participant would repeat the name of their colleague, then introduce themselves with another adjective for their name, and so on; for example: Loving Luke, beautiful Bruna and wonderful Wendy.

At a second moment, the face dynamic technique was discussed, in which each adolescent should raise one of two boards, which had two faces - a sad and a happy one - at each question asked. The questions were: "What is leprosy? What do you think about leprosy? What do your parents, friends and neighbors think? Have you ever had this disease? If so, tell me about your experience. What are your fears, doubts and feelings regarding leprosy?" After raising the board, each adolescent should justify their answer. At the end of the questions, the Nursing students discussed the concepts of leprosy with the adolescents, as well as the stigma and prejudice regarding the disease.

In a third moment, the topic worked consisted of classification, signs, symptoms and transmission of leprosy, through the traffic light dynamic technique, applied consecutively in that order. Prints were selected containing the types of disease classification, signs, symptoms and transmission of leprosy and of other endemic diseases. The triggering questions were: "Do you know what is the classification and which are the signs and symptoms of leprosy? Do you know how leprosy is transmitted?"Each student placed a print on a card (red, yellow and green) to classify the disease (severe, mild and not severe) to identify signs and symptoms (risk to the disease, attention to the disease and not characteristic of the disease) and how it is transmitted (risk, attention and without risk). At the end of the game, the undergraduate students discussed with the adolescents the classification, signs and symptoms of leprosy, the way the disease is transmitted, in addition to clarifying myths and taking about the reality of leprosy transmission.

The forth part of the workshop corresponds to the dynamic technique of true ( $T$ ) or false (F). Several prints were selected on ways to diagnose and treat leprosy and other diseases. Questions like the following were asked: "Do you know how the diagnosis and treatment of leprosy are performed?" Under the prints, the adolescents placed the letter " $T$ " if they believed that it was a correct way to diagnose and treat leprosy, or " $F$ " if they believed that the diagnosis and treatment illustrated in the print were not related to leprosy. At the end of the dynamics, the ways to diagnose and treat leprosy were discussed, stressing the importance of the treatment to cure and prevent disabilities.

Finally, the workshop was ended through the mosaic dynamic technique, which consisted in cutting magazine pictures, presenting the representation/meaning of the participation in the educational workshop by the adolescents.

\section{Experience in the educational workshop implementation on leprosy with adolescents}

During graduation, Nursing students acquire little contact with the leprosy topic, which makes pertinent their participation in extension projects that address the subject, providing connections between the daily life of professional practice and theory. There is also the possibility of immersing in studies regarding the disease and the methods to discuss health education with adolescents, which contributes to their professional training. Thus, the participation of Nursing students in demonstrating the dynamic techniques was of great importance, since it provided autonomy to apply the workshops afterwards with the adolescents.

Prior to the application of the workshop, it was necessary to contact the public administrators of each school in order to request authorization to develop the project. Facilities and difficulties were identified during this process. Some administrators were in favor of the workshop in their schools, because they believed in the potential and importance of the project, and became partners. It was noticed that there was greater adhesion in schools in which the administrators encouraged the participations of adolescents. Administrators that did not support the project pointed out as obstacles: teachers unfavorable to the development of the workshop, believing it would impair their classes; lack of rooms to perform it; poor infrastructure; and due to the school calendar.

After authorization of each school, the project was presented to adolescents who, mostly, showed no interest in the subject, refusing to participate in the workshop. Still, among the interested, some did not give the forms to their parents, others forgot them at home or their parents did not authorize them, with the justification that their son/daughter did not have the disease, therefore, they did not need to participate in the workshop and learn about leprosy, according 
to the reports of the adolescents themselves. This highlights the lack of attitude regarding the topic on part of parents/guardians and adolescents.

The workshop took place in the spaces provided in classrooms, the library and school cafeteria. A few negative aspects to conduct the workshop were found, such as reduced space, noises and interruptions in recesses, which caused a lack of concentration and dispersion of the participants. Even facing these difficulties, the workshop application with a reduced number of adolescents was essential to ensure attention, involvement and the best behavior of these students.

The initial "icebreaker" dynamic technique was important in the first contact with the teenagers, allowing relaxation and interaction between applicators and participants of the workshop. When the general aspects of leprosy were addressed, we observed that adolescents attribute false concepts to the subject and showed fears, myths, doubts, anxieties and concerns, especially regarding the method of transmission and the risk of death. They thought that the disease was transmitted through hugging, kissing and handshakes, and there is no cure, although there were many reports of cases of the disease in family members. In this sense, the workshop program allowed to mutually build knowledge, considering the previous knowledge of the participants and their experiences, discussing false concepts, stigma and prejudice.

In the course of the workshop, it was possible to notice personality differences among the adolescents, and most of them had a good interaction with the group, were communicative, actively participated expressing their ideas, giving opinions and clarifying doubts, reinforcing the advantages of the technique used to developed the workshop. However, others had a more introspective posture, with little interaction and participation, possibly due to characteristics of the individual.

The last moment allowed to understand that the adolescents who were more involved during the process verbalized better the acquired knowledge on the general aspects of the disease. In general, they claimed to have liked to participate in the workshop, they were happy to know more about the disease and to be able to act in the society they live in through identifying signs and symptoms of the disease, sharing knowledge and guiding regarding health services.

We observed that the available time for the workshop was enough to perform the planned dynamic techniques. The techniques used facilitated the progress of the workshop, because they allowed more involvement from the adolescents, who stated being favorable to this method of application.

\section{Limitations of the study}

We highlight as a limitation of the study the fact that it deals strictly with the experience of the authors involved in this project, without a robust evaluation of the effectiveness of such educational intervention.

\section{Contributions to the nursing field}

Considering that the nurse performance in primary health care goes beyond the doctor's office and that health education is an activity intrinsic to this professional, its performance in schools and other services in their area of influence is indispensable, taking advantage of all opportunities to contact adolescents and their families to developed health education activities, especially regarding an event with high incidence in their area of influence.

In this perspective, the school environment is an ideal space to exercise educational interventions, in which the playfulness becomes extremely important when one intends to work with this public. Dynamics are resources that allow individual expression and building a collective knowledge, producing from the exchange of knowledges between students and the nurse professional - a primary precursor of educational actions.

\section{CONCLUSION}

It is concluded that the applied workshops had a positive impact on the school community, since the adolescents participated actively of the health education process, in which the construction of knowledge and debunking myths and socially constructed stigmas were observed, promoting the emancipation of the subjects regarding the topic of leprosy.

This experience allowed nursing students to expand their scientific knowledge on leprosy and experiencing educational interventions, applying dynamics with adolescents, understanding the importance of planning, implementing and assessing the activity, assimilating the necessity of using appropriate methods to work with the target audience.

\section{FUNDING}

Universidade Federal de Mato Grosso/Pró-Reitoria de Cultura, Extensão e Vivência (UFMT/Procev).

\section{REFERENCES}

1. Romero-Montoya IM, Beltran-Alzate JC, Ortiz-Maríi DC, Diaz-Diaz A, Cardona-Castro N. Leprosy in Colombian children and adolescents. Pediatr Infect Dis J. [Internet] 2014 [cited 2017 Mar 25];33(3):321-2. Available from: https://www.ncbi.nlm.nih.gov/pubmed/24030349

2. Barreto JG, Bisanzio D, Guimarães LS, Spencer JS, Vazquez-Prokopec GM, Quitrom U, et al. Spatial analysis spotlighting early childhood leprosy transmission in a hyperendemic municipality of the Brazilian Amazon region. PLoS Negl Trop Dis [Internet]. 2014 [cited 2017 Mar 30];8(2):e2665. Available from: http://www.cnpq.br/documents/10157/cb450892-8f47-4aa4-9bce-24592bb46ba5

3. World Health Organization. Global leprosy update, 2015: time for action accountability and inclusion. Wkly Epidemiol Rec [Internet]. 2016[cited 2017 Jan 10];91(35):405-20. Available from: http://apps.who.int/iris/bitstream/10665/249601/1/WER9135.pdf?ua=1.pdf

4. Ministério da Saúde (BR). Sala de Apoio à Gestão Estratégica (Sage). Situação epidemiológica da hanseníase no Brasil (SINAN/SVS/MS) [Internet]. sd[cited 2017 Jan 11]. Available from: http://sage.saude.gov.br/ 
5. Freitas BHBM, Cortela DCB, Ferreira SMB. Trend of leprosy in individuals under the age of 15 in Mato Grosso (BR), 2001-2013. Rev Saúde Públ [Internet]. 2017[cited 2017 Jan 2];51(28):1-9. Available from: http://www.scielo.br/pdf/rsp/v51/0034-8910-rsp-S1518-87872017051006884.pdf

6. Ministério da Saúde (BR). Secretaria de Vigilância em Saúde. Departamento de Vigilância das Doenças Transmissíveis. Diretrizes para vigilância, atenção e eliminação da Hanseníase como problema de saúde pública: manual técnico-operacional [Internet]. Brasília (DF); 2016 [cited 2017 Jan 10]. Available from: http://portal.saude.pe.gov.br/sites/portal.saude.pe.gov.br/files/diretrizes_para_._eliminacao_ hanseniase_-_manual_-_3fev16_isbn_nucom_final_2.pdf

7. Coscrato G, Pina JC, Mello DF. Use of recreational activities in health education: Integrative review of literature. Acta Paul Enferm [Internet]. 2010 [cited 2017 Jan 10];23(2):257-63. Available from: http://www.scielo.br/pdf/ape/v23n2/en_17.pdf

8. Mariano MR, Pinheiro AKB, Aquino OS, Ximenes LB, Pagliuca LMF. Jogo educativo na promoção da saúde de adolescentes: revisão integrativa. Rev Eletr Enferm [Internet]. 2013[cited 2017 Jan 20];15(1):265-73. Available from: https://revistas.ufg.br/fen/article/ view/17814/15546

9. Jesus JMF, Alencastro MAB. Práticas educativas sobre hanseníase com adolescentes: revisão integrativa da literatura. [Monografia]. Cuiabá: Universidade Federal de Mato Grosso (BR); 2017. 22 p.

10. Yonekura T, Soares CB. O jogo educativo como estratégia de sensibilização para a coleta de dados com adolescentes. Rev Latino-Am Enfermagem [Internet]. 2010 [cited 2017 Mar 24];18(5):7 telas. Available from: http://www.scielo.br/pdf/rlae/v18n5/pt_18 